\title{
Classical Lissencephaly
}

National Cancer Institute

\section{Source}

National Cancer Institute. Classical Lissencephaly. NCI Thesaurus. Code C84640.

A genetic disorder caused by mutations in the LIS1, XLIS, or TUBA1A genes. It results in brain malformation characterized by the underdevelopment or absence of gyri or ridges in the cerebral cortex. Signs and symptoms include epilepsy and mental retardation. 